\title{
Foro por prerrogativa de função: prefeitos municipais
}

\author{
Stella Furlanetto de Mattos Cunha ${ }^{1}$
}

\begin{abstract}
Resumo
Analisa 0 foro pela prerrogativa de função, também denominado de foro privilegiado, aplicado aos Prefeitos M unicipais, com a promulgação da Constituição Federal de 1988. Busca o fundamento e a relação desse foro por prerrogativa de função com o princípio da isonomia, assim como delimita sua aplicabilidade ao estabelecer a distinção entre crime comum, crime de responsabilidade e infração político-administrativa. Relaciona 0 foro por prerrogativa de função, com a competência originária do Tribunal Regional Eleitoral, do Tribunal Regional Federal e - Tribunal de Júri. Demonstra a necessidade de delimitar a intervenção das "justiças" especiais ou comuns, a participação popular direta no exercício da jurisdição, assegurada com a competência privativa do júri para alcançar a harmonização com o interesse de resguardar a dignidade e importância para 0 Estado de determinados órgão públicos, que justifica a chamada competência pela prerrogativa de função. Por fim, analisa o cancelamento da Súmula 394 da Suprema Corte e o cabimento do foro especial, depois de cessado a função pública desempenhada.
\end{abstract}

Palavras-Chave: Competência; Foro pela Prerrogativa de Função; Prefeitos Municipais.

\section{Introdução}

0 presente artigo se dedica à discussão da aplicabilidade do foro pela prerrogativa de função para os prefeitos municipais em concurso aparente com o Tribunal Regional Eleitoral, 0 Tribunal Regional Federal e o Tribunal do Júri.

A competência pela prerrogativa de função entendida como a necessidade de resguardar o interesse de ordem pública de maior relevância no processo, como a dignidade e importância de determinados cargos públicos, embora haja entendimentos que tal prerrogativa seja um privilégio.

A competência por prerrogativa de função aplicada aos Prefeitos M unicipais passou a vigorar na Constituição Federal de 1988, no seu artigo 29, X, razão pelo qual devem ser julgados pelo Tribunal de Justiça e que a mesma deverá ser analisada sob o enfoque dos

\footnotetext{
${ }^{1}$ Acadêmica do 50 ano matutino do curso de Direito da Universidade Estadual de Londrina.
} 
princípios fundamentais do nosso Estado Democrático de Direito, o princípio da isonomia e o princípio do juiz natural.

Será foi abordado a hipótese da pretensão punitiva fundada em fatos que configuram crimes eleitorais cometido pelo Chefe do Poder Executivo Municipal, em face da competência originária atribuída ao órgão superior, o Tribunal de Justiça.

Assim como a atuação da justiça federal diante da recomendação da intervenção de órgãos da União e não dos Estados - Membros e a competência originária do Tribunal de Justiça, atribuída ao Prefeito em razão do foro por prerrogativa de função, no que se refere às infrações delituosas que afrontam bens, serviços ou interesses da União, de suas autarquias ou de empresas públicas federais.

Estuda-se 0 confronto aparente de interesse ao atribuir ao Tribunal do Júri, constitucionalmente previsto no art. $5 \stackrel{\circ}{\circ}$, inc. XXXVIII, a competência em detrenimento do foro por prerrogativa de função.

O Júri entendido como instituição consagrada pelo constitucionalismo pátrio refletindo uma projeção concretizadora das liberdades públicas, direito fundamental inalienável e oponível ao próprio Estado.

Análise do cancelamento da Súmula 394 da Suprema Corte e a continuidade de aplicar o foro especial para ex - ocupantes do cargo público, concomitantemente com a Lei 10.628/2002, que acrescentou 0 §1 no antigo 84 do Código de Processo Penal, a qual possibilitou ex - agentes públicos a continuidade de serem processados e julgados originariamente por órgãos jurisdicionais superiores.

\section{Jurisdição - noções}

Nas palavras de Guilherme Nucci (2007, p. 223) jurisdição "é o poder atribuído, constitucionalmente, ao Estado para aplicar a lei ao caso concreto, compondo litígios e resolvendo conflitos".

Dessa maneira, todo juiz, investido na sua função, possui jurisdição, podendo se utilizar da força estatal para fazer cumprir sua decisão compulsoriamente, a fim de compor conflitos emergentes na sociedade. No que se refere ao direito penal, o Estado detendo 0 monopólio, evita a autotutela, a qual pode acarretar insegurança e revolta social.

Para M agalhães Noronha (2002, p. 57) jurisdição pode ser assim entendida: 
[...] com particularidade ao juízo criminal diremos que ela é o poder concedido ao juiz de decidir, aplicando a lei, com o fim de sujeitar o réu à sanção penal, absolvelo ou declarar extinta a punibilidade. É a função primacial e mesma excelsa da Justiça Criminal.

Como sucede com qualquer atividade jurisdicional, também 0 exercício da jurisdição penal é informado por relevantes garantias constitucionais que buscam assegurar a imparcialidade do juiz. Visto o processo como contraposição dialética entre acusação e defesa, justificando a necessidade da imparcialidade do juiz, sem ela, não há efetivo contraditório, não há segura contradição entre as partes. A essa garantia ligam-se, no plano constitucional, as próprias garantias da Magistratura, como a da vitaliciedade. Deve o juiz sentir-se seguro para atuar de maneira justa e imparcial, eqüidistante das partes. Também se ligam à imparcialidade do juiz a garantia constitucional do Juiz Natural, que, no juízo penal, constitui importante proteção à liberdade do cidadão, bem como a garantia da motivação das decisões judiciais.

Competência: critérios de fixação e objeto de estudo

Admitindo e entendendo a existência da jurisdição é necessário compreendermos o que significa competência e quais os critérios de sua fixação.

Competência é a capacidade de exercer a jurisdição dentro dos limites estabelecidos pela Constituição Federal e legislação ordinária. Fala-se, então, que a competência é o "limite da jurisdição", ou a "medida da jurisdição", ou ainda a "quantidade de jurisdição". Nesse sentido a lição de Liedman, citado por Athos Gusmão Carneiro (2004, p.61) em seu livro.

[...] a competência é a quantidade de jurisdição cujo exercício é atribuído a cada órgão, ou seja, a 'medida da jurisdição'. Em outras palavras, ela determina em que casos e com relação a que controvérsias tem cada órgão em particular o poder de emitir provimentos, ao mesmo tempo em que delimita, em abstrato, o grupo de controvérsias que lhe são atribuídas.

Competência ratione materiae, ratione personae e ratione loci

Busca-se então em primeiro plano, o lugar da infração penal (ratione loci), e a partir disso, visualiza-se as exceções: quando houver matéria especial a ser cuidada (ratione 
materiae), considerando a natureza da infração (é o que ocorre com a Justiça Militar ou Eleitoral, para crimes militares ou eleitorais); e quando houver "privilégio" quanto ao órgão competente para processar e julgar em razão da função, do cargo político que a pessoa (ratione personae) a ser julgada ocupa.

Uma vez fixada a competência em razão da matéria, temos que verificar o grau do órgão jurisdicional competente, ou seja, observar se o órgão incumbindo do julgamento é o juiz, o tribunal ou o tribunal superior, caso o sujeito do processo penal tenha condições especiais que permite uma delimitação de acordo com a função desempenhada, esta estabelecida pela Constituição Federal, chamada de prerrogativa de função, também denominada de ratione personae.

\section{Competência pela prerrogativa de função}

Assim como nos lembra o Fernando Capez (2001.p.163), ao ser instituído pela Constituição Federal a competência ratione persone e conferido para determinadas pessoas, devido à relevância da função exercida, o direito de serem julgadas em foro "privilegiado" não ofende o princípio da isonomia, "uma vez que não se estabelece a preferência em razão da pessoa, mas da função".

A definição constitucional das hipóteses de prerrogativa de foro, ratione muneris, representa elemento vinculante da atividade de persecução criminosa do Poder Público. É que o Estado não pode desconsiderar essa garantia básica que predetermina, em abstrato, os órgãos judiciários investidos de competência funcional para a apreciação de litígios penais que envolvam determinados agentes públicos (FRANCO, 2001, p. 163).

Estende-se a competência do Tribunal de Justiça do Estado sobre seu jurisdicionado a qualquer região do território nacional, já que o foro por prerrogativa de função exclui a regra do foro pelo lugar da infração, o Tribunal de Justiça competente é o do Estado da respectiva autoridade, ainda que o crime tenha sido praticado em outro Estado (MIRABETE, 2006, p. 179).

Alguns autores distinguem as expressões "foro privilegiado" (privilégio para determinadas pessoas) e "foro por prerrogativa de função" (foro especial fixado como garantia inerente ao exercício de uma função), entendendo que somente o primeiro viola 0 princípio da isonomia. 
0 princípio da isonomia também chamado de princípio da igualdade está previsto no art. 50, caput, da Constituição de 1988, essa igualdade estabelecida em lei é premissa para a afirmação da igualdade perante o juiz, ou seja, a igualdade processual, que garante às partes e aos procuradores a mesma oportunidade de fazer em juízo as suas razões (CINTRA, 2003, p. 53).

De acordo com Ada Pellegrini Grinover e Cândido Rangel Dinamarco (2003, p. 53), "a absoluta igualdade jurídica, não pode, contudo, eliminar a desigualdade econômica".

Daí 0 entendimento, de que o conceito primitivo e formal de igualdade, na qual "a lei não deve estabelecer qualquer diferenças entre os indivíduos", não corresponde com a denominada igualdade substancial. Hoje, aplica-se o conceito positivista de isonomia, "iguais oportunidades para todos, a serem propiciadas pelo Estado", buscando-se dessa maneira a igualdade proporcional, o que significa, "tratamento igual aos substancialmente iguais" (CINTRA, 2003, p. 54).

Ainda de acordo com Ada Pellegrini Grinover e Cândido Rangel Dinamarco (2003, p. 54), "essa aparente quebra do princípio da isonomia, dentro e fora do processo, obedece exatamente ao princípio da igualdade real e proporcional, que impõe tratamento desigual aos desiguais, justamente para que, suprimidas as diferenças, se atinja a igualdade substancial".

Interessante acrescentar os ensinamentos de Hélio Tornaghi (1959, p. 55-56), no que diz respeito à competência por prerrogativa de função, previsto no Código de Processo Penal, mas que não sugere um foro privilegiado. Não há foro especial "para conde, barão ou duque; para Jafet, Café ou Mafé;" diz o mesmo autor, a lei não tem preferências nem predileções, apenas considera a dignidade da função, a altitude do cargo, a iminência da posição, tanto é assim que se a pessoa deixa a função, perde a prerrogativa, "que não é sua, mas dela".

Segundo Frederico Marques (1961, p. 206-207), a competência ratione personae dos Tribunais Superiores não é um foro privilegiado e desprovido de preceitos pertinentes aos juízos especiais, pois no processo penal, "o que se ensina é que, em lugar de privilégio, o que se contém nessa competência ratione personae constitui, sobretudo, uma garantia".

Fernando Capez (2004, p. 189), afirma que o foro por prerrogativa visa preservar a independência do agente político, no exercício de sua função, e garantir o princípio da 
hierarquia, não podendo ser tratado como se fosse um simples privilégio estabelecido em razão da pessoa.

A competência pela prerrogativa de função vem fixada nos artigos: 102, inciso I, alínea b e c; 105, inciso I; 108, inciso I, alínea a; 96, inciso III; 29, inciso X e 125, § 1ㅇ.

Define - se foro por prerrogativa de função segundo Tourinho (2004, p.279):

[...] há determinados pessoas, independente de condições de fortuna, posição social, raça ou credo, que exercem, no cenário jurídico político da nossa terra, funções relevantes e, em atenção a essas funções, gozam elas de foro especial, isto é, não são processadas e julgadas, como qualquer do povo, pelos órgãos comuns, mas pelos Tribunais.

Dessa maneira podemos dizer que foro por prerrogativa de função é o poder concedido a órgãos superiores do Poder Judiciário para processar e julgar pessoas que exercem determinadas funções de relevância para o Estado, justificando o tratamento diferenciado.

A competência por prerrogativa de função é entendida por M irabete $(2003$, p. 328) como sendo uma "medida de utilidade pública", pois trata-se de uma competência ratione personae (em razão da pessoa), "ditada pela função da pessoa, bem como a dignidade do cargo exercido, não o do indivíduo que a merece".

Diante da eleição legal de um foro privilegiado, como prefere denominar Guilherme Nucci (2007, p. 239), para julgar determinado réu, que cometeu infração penal, no tempo em que exercia atividade funcional especial, relevando - se as demais regras naturais de competência, passando a respeitar o foro específico, baseado na qualidade da pessoa em julgamento.

Porém, para Nucci (2007, p. 239), se todos são iguais perante a lei, "seria preciso uma particular e relevante razão para não afastar o criminoso do seu juízo natural".

E ainda continua.

[...] não vemos motivo suficiente para que Prefeito seja julgado na Capital do Estado, nem para que o juiz somente posse sê-lo pelo Tribunal de Justiça ou desembargador pelo Superior Tribunal de Justiça e assim por diante. Se à Justiça Cível todos prestam contas igualmente, sem qualquer distinção, natural seria que a regra valesse também para a Justiça Criminal. 0 fato de se dizer que não teria cabimento um juiz de primeiro grau julgar um Ministro de Estado que cometa um delito pois seria uma 'subversão hierárquica' não é convincente, visto que os 
magistrados são todos independentes e, no exercício de suas funções jurisdicionais, não se submetem a ninguém, nem há hierarquia para controlar o mérito de suas decisões. Logo julgar, um Ministro de Estado ou um cidadão qualquer exige do juiz a mesma imparcialidade e dedicação, devendo-se clamar pelo mesmo foro, levando em conta o lugar do crime e não a função do réu. (NUCCl, 2007, p. 239)

Seria o foro privilegiado "tal qual uma prisão especial, é herança de uma legislação elitista, que muito se compatibilizou com regimes baseados na força e no prestígio da autoridade" (NUCCl, 2007, p. 240).

Porém, uma vez previsto em nossa Lei Maior, significa que a igualdade formal, está sendo respeitada, já que as regras constitucionais estão sendo aplicadas a todo isonomicamente, razão pela qual o foro pela prerrogativa de função deve ser respeitado, mas futuramente alterado (NUCCl, 2007, p. 240).

\section{Prefeitos municipais e o foro por prerrogativa}

Falamos em concurso aparente de regras constitucionais sobre competência, pois trata-se de uma situação temporária que basta sobrepesarmos interesses de ordem pública e utilizarmos daquele critério que mais se aproxima das diretrizes do nosso Estado Democrático de Direito e encontraremos o juízo competente.

A delimitação da competência está estritamente vinculada a interesses de ordem pública de maior relevância, como acima já citado, lidando com o objetivo de resguardar determinados cargos públicos de suma importância para o Estado e com a difícil tarefa de impor limites de intervenção dos órgãos jurisdicionais especiais e comuns, aplicando - os ora isoladamente ora cumulativamente.

Nesse sentido quando a Constituição Federal trata diversamente impondo competência originária a órgãos superiores "fundada em fatos configuradores no processo de pretensão punitiva atribuída a ocupantes de cargos públicos, cuja dignidade e importância para o Estado se sobrepõem, temos a denominada prerrogativa de função, em relação á organização judiciária especializada" (KARAM, 2005, p. 113-114).

O foro por prerrogativa de função dos Prefeitos passou a vigorar na Constituição Federal de 1988, razão pela qual devem ser julgados pelo Tribunal de Justiça.

Sobre a razão de se aplicar esta prerrogativa, diz, André M edeiros do Paço (2000, p. 18), que: 
[...] o objetivo do foro privilegiado é que se faca o processo e julgamento dos melhores pelos melhores. 0 adjetivo está obviamente ligado ao especial destaque do cargo publico ocupado pela pessoa, o que de certa forma tem caráter indiciário. Ou seja, se alguém esta exercendo funções de tamanha importância para a sociedade, presume-se que seja portador de qualidades especiais - o que, infelizmente, muitas vezes não corresponde à verdade.

André M edeiros do Paço $(2000$, p. 38) cita Borges da Rosa, que por sua vez critica a expressão "competência pela prerrogativa de função", porque toda função pública tem atribuições que the são próprias, que a distinguem de outras funções, parecendo-lhe a concessão de um "privilégio". Prefere a designação "competência em razão das pessoas", ligada à qualidade pessoal do acusado, exercendo temporariamente ou permanentemente uma determinada função pública.

Partiremos da interpretação da regra do art. 29, inciso X, da Constituição Federal (originariamente inciso VIII, enumerada novamente pela Emenda Constitucional n.1, de 31 de março de 1992), a qual introduziu entre as funções cujo exercício submete-se a competência originária de órgãos jurisdicionais superiores, a decorrente da investidura no cargo de prefeito municipal, atribuindo aos Tribunais de Justiça competência originária para o exame de causas em que figuram como autores do crime ocupantes daquele cargo público.

Decidiu o Supremo Tribunal Federal que a competência originária do Tribunal de Justiça, em que figure com réu prefeito municipal em processo penal condenatório, restringe-se a hipóteses relativas a infrações penais sujeitas à competência da Justiça local. Já o Tribunal Regional Federal possui competência originária para o conhecimento de causas em que se atribua aos ocupantes daquele cargo crimes contra bens, serviços ou interesses da União, de suas autarquias ou de empresas públicas federais. ${ }^{2}$ Em matéria de delitos eleitorais, originariamente compete o Tribunal Regional Eleitoral. ${ }^{3}$

Tal entendimento resultou no verbete da Súmula 702 do Supremo Tribunal Federal, assim disposto: "A competência do Tribunal de Justiça para julgar Prefeitos restringe-se aos crimes de competência da justiça comum estadual; nos demais casos, a competência original caberá ao respectivo tribunal de segundo grau".

\footnotetext{
${ }^{2}$ HC 78.728-2, da 2a Turma, rel. M in. Mauricio Corrêa, j. 23.02.1999, DJU 16.04.1999, p. 8.

3 Decisão unânime do Plenário do Tribunal Regional Eleitoral no Inq. 406-5, rel. Min. Celso de Mello, j. 01.07.1993, DJU 03.09.1993, p. 17.741.E também neste sentido STF Plenário, HC 67.480, DJU 10.9.89, p. $14330 / 31$
} 


\section{Crimes de responsabilidade e crimes comuns}

Faz-se necessário a distinção entre crimes comuns e os de responsabilidade.

Os crimes comuns, constitucionalmente falando, são entendidos como aqueles que compreendem todas as modalidades de delitos desde que não se capitulem entre os crimes de responsabilidade.

Diante da dificuldade e toda confusão trazida por leis que tratavam de foro por prerrogativa de função, utilizando-se de diferentes expressões muitas vezes citadas em contextos diferentes, não estabelecendo significado uniforme, Hely Lopes M eirelles, redigiu o Decreto - Lei 201 de 21.02.1967, com o intuito de solucionar tal celeuma jurídico. Separou a responsabilidade de Prefeitos e Vereadores sob ótica política e ordinária, denominando de crimes de responsabilidade, os crimes comuns cometidos por Prefeitos Municipais no exercício da função, ou seja, deu a eles o sentido de crimes funcionais, crimes próprios, julgados pelo Poder Judiciário.

Estão definidos os crimes de responsabilidade do Prefeitos municipais, sujeitos ao julgamento do Poder Judiciário, independente do pronunciamento da Câmara dos Vereadores, no art. 10 do Dec.-Lei 201/67.

A doutrina de Tito Costa $(2002$, p.40) aceitando tal modo de expressar, embora carente de significado condizente com 0 fato jurídico em questão define crime de responsabilidade como "os delitos de natureza funcional, cometidos por Prefeitos municipais, no exercício das funções executivas do governo local e em decorrência desse exercício". E a ainda acrescenta "Sujeito Ativo, da infração é, pois, o Prefeito, e só ele", salvo na hipótese de co-autoria "incidirá nas penas a ele cominadas".

Nota-se que, hoje é perfeitamente acolhido o uso da expressão "crimes de responsabilidade", definitivamente no art. 1o do Dec. - Lei 201-67, cujo, sentido se delimita a crimes funcionais de agentes políticos, Prefeitos.

Por sua vez, o Superior Tribunal de Justiça, ao editar a Súmula 164, fixou que "Prefeito Municipal, após a extinção do mandato, continua sujeito a processo por crime previsto no artigo 1을 do Decreto-Lei 201, de 27.02.1967".

Estudioso do tema, Tito Costa (2002 p.43), resume "o Judiciário julga os crimes; a Câmara aprecia as infrações político - administrativas." Cada um atuando sem invadir a 
esfera de atuação do outro, sob pena, de constituir lesão a direito líquido e certo, tendo como remédio processual, o mandado de segurança, ou até mesmo o habaes corpus.

Não exime o ocupante do cargo público de chefe executivo municipal a prática de crimes comuns, ou seja, que não importa a sua condição de Prefeito, e sim como cidadão, independente da função desempenhada.

Os crimes de responsabilidade é um crime funcional, ou seja, aquele decorrente do exercício da atividade laborativa nos cargos públicos, tendo como elementar ou circunstância especial do tipo a qualidade de funcionário público, estes considerados relevantes para o Estado.

Entende o ilustre Tito Costa (2002.p.43), que, assim sendo, ficou instituído pela Constituição Federal o foro especial para prefeitos o Tribunal de Justiça, como órgãos competente para o julgamento deste decorrente de crimes de responsabilidade.

Diferentemente do entendimento anterior, Mirabete (2003, p. 328), diz que a competência originária do Superior Tribunal de Justiça, dos Tribunais Regionais Federais e dos Tribunais de Justiça dos Estados e do Distrito Federal é passível de processar e julgar crimes comuns e de responsabilidade, segundo o estabelecido da Constituição Federal e nas Constituições dos Estados.

Assim, a jurisprudência, tem entendido que, como não é feita a distinção entre crimes comuns e de responsabilidade, 0 art.29 inc $\mathrm{X}$, da CF/88, abrange ambos, desde que sejam submetidos à Justiça Estadual.

Competência da justiça eleitoral e competência por prerrogativa de função

Diante da omissão do art. 29, inc. X, da Constituição Federal, em não ressalvar a natureza de infrações penais passível de julgamento pelo Tribunal de Justiça estudaremos como ficará delimitada a competência para processar e julgar prefeitos municipais em crimes eleitorais.

Segue o comentário de Maria Lúcia Karam (2005, p. 116) a respeito da competência da justiça eleitoral:

[...] a Constituição Federal ressalva a competência desta justiça em diversos dispositivos, deixando claro que somente em casos excepcionais (como na hipótese de competência originaria do Supremo Tribunal Federal) a preponderância do 
interesse criador da prerrogativa de função afastará a intervenção dos órgãos jurisdicionais instituídos especialmente para examinar a matéria eleitoral. Não há dúvida, assim, que, inobstante a inexistência de ressalva na regra contida no art. $29 \mathrm{~m}$ inciso $X$, as particularidades da matéria tratada determinam que a consideração de prerrogativa de função, também quando seja parte no processo ocupante do cargo de prefeito municipal, se faça de forma limitada, tão somente levar a órgãos jurisdicionais superiores da justiça eleitoral (os Tribunais Regionais Eleitorais) 0 conhecimento originário da causa.

Fica evidente que segundo o entendimento da autora supra citada, a competência por prerrogativa de função não prevalecerá em razão do órgão eleitoral de segundo grau (Tribunal Regional Eleitoral).

Além do que a nossa Constituição prevê que quanto ao âmbito da competência originária dos Tribunais de Justiça deve-se dele retirar a matéria eleitoral, como deixa expressa a regra contida no artigo 96, inciso III (KARAM, 2005, p. 117). Cabe ao Tribunal Regional Eleitoral processar e julgar crimes eleitorais cometidos por prefeitos municipais.

Embora tenhamos posicionamentos em diferentes sentidos, no que diz respeito à matéria eleitoral, majoritariamente, a competência delimitada pelo foro por prerrogativa de função, cujo órgão competente para processar e julgar originariamente prefeitos seria 0 Tribunal de Justiça, não deve ser aplicada, pois neste caso vigorará a prevalência do órgão especializado, Tribunal Regional Eleitoral, para o processo e julgamento de crimes eleitorais, cujo sujeito da infração delituosa é o prefeito.

\section{A competência do tribunal regional federal e o foro especial}

Estudaremos as hipóteses em que se aplica o foro por prerrogativa de função ou será atribuída competência à Justiça Federal.

Neste caso há o confronto da dignidade e importância dos cargos públicos ocupados por prefeitos e a necessidade de atuação dos órgãos da União e não dos Estados Membros.

Nota-se que afasta a competência de órgãos da justiça federal comum, diante da regra constitucional (artigo 96, inciso III), unicamente a magistrados e órgãos do M inistério Público locais, sendo privativa a atuação dos Tribunais de Justiça, não aplicando a mesma regra para Prefeitos, dessa maneira não vigora o foro por prerrogativa de função (Tribunal 
de Justiça) e sim competente será a Justiça Federal, assim como previsto no art. 109, CF (KARAM, 2005, p. 118).

Maria Lúcia realizou este estudo, portanto:

[...] A competência do Tribunal de Justiça deve se restringir à hipótese de se atribuir a prefeito municipal infração penal que, por sua natureza, deve ser examinada pela justiça local, impondo - se a atuação jurisdicional da justiça federal no caso das infrações cuja natureza determina sua competência, aqui entendidas as regras que a definem como regras especiais, devendo, naturalmente, o processo se desenvolver perante 0 Tribunal Regional Federal, diante de entendimento resultante de construção jurisprudencial, já aqui lembrado, segundo o qual a autoridade que tem no Tribunal de Justiça o foro por prerrogativa de função deve ser processada e julgada perante Tribunal a que corresponder o juízo singular que em princípio seria o competente, de forma a harmonizar os interesses confrontados (no caso em exame, a necessária consideração da dignidade e importância para o Estado dos cargos públicos ocupados por prefeitos municipais, a determinar a competência originária de órgãos jurisdicionais superiores, defrontada com a necessária atuação no processo de órgãos jurisdicionais da justiça federal, dada a matéria tratada, a recomendar a intervenção de sistemas integrado de órgãos da União e não dos Estados Membros (KARAM, 2005, p.118).

Analisando a competência do Tribunal Regional Eleitoral e do Tribunal Regional Federal, notamos que ambas estão fixadas na Constituição Federal e que por usa vez não contém norma implícita ou explícita que permite a esse Tribunais processar e julgar outras pessoas além das elencadas, seria mais benéfico manter tal rigidez, segundo Tourinho Filho (2004, p. 296) e possibilitar que o próprio Tribunal de Justiça seja responsável por tais processos, afim de interpretar extensivamente a Lei M aior. Além do que, atribuir ao Tribunal Regional Federal, competência para processar e julgar crimes de cunho federal cometido por Prefeitos Municipais, estaria desvinculando - os do princípio do Juiz Natural, como anteriormente citado, já que nem a Constituição Federal e nem tampouco a lei ordinária atribui poderes a tal ponto.

No caso de crime contra a Administração Pública praticado em detrimento da União, como por exemplo, na apropriação por Prefeito Municipal de verba federal sujeita a prestação de contas perante o Tribunal de Contas da União, a competência será do Tribunal Regional Federal. ${ }^{4}$

\footnotetext{
${ }^{4}$ Nesse sentido: STF, HC 72-673-9/AL, rel. Min. IImar Galvao, DJU, 6 out. 1995, p.33131
} 
Em razão da matéria o Superior Tribunal de Justiça editou a Súmula 208, segundo a qual: "Compete a Justiça Federal processar e julgar prefeito municipal por desvio de verba sujeita a prestação de contas perante órgão federal".

Explica Fernando Capez (2004, p. 102), "se a Corte de Contas Federais detém competência para fiscalizar a verba cedida ao Município, é porque persiste 0 interesse da União, do que deriva estarem os atos do prefeito sujeitos ao controle jurisdicional do Tribunal Regional Federal".

Necessário mencionarmos que se a verba federal transferida ao Município já estiver incorporada ao patrimônio municipal, a competência para julgar o prefeito será do Tribunal de Justiça, não havendo interesse da União. É o que dispõe a Súmula 209 do STJ: “Compete a Justiça Estadual, processar e julgar prefeito por desvio de verba transferida e incorporada ao patrimônio municipal".

0 Tribunal Regional Federal é também competente originariamente para processar e julgar os crimes políticos, estes, ensina, André Medeiros do Paço (2000, p. 59) citando Nelson Hungria "são os dirigidos, subjetiva e objetivamente, de modo imediato, contra o Estado como unidade orgânica das instituições políticas e sociais". São os crimes definidos Lei 7.170, de 14.12.1983.

Também compete ao Tribunal Regional Federal o processo e julgamento no concurso de infrações penais de jurisdições diversas. ${ }^{5}$

No que se refere à quota federal do produto da arrecadação do salário-educação, parcialmente destinada à assistência financeira aos sistemas locais de ensino fundamental, na razão da carência de recursos próprios, do menor desenvolvimento e dos maiores déficits de escolaridade infantil. Não são, dessa maneira, subsídios discricionariamente concedidos pela União aos M unicípios, mas sim a realização da própria função da União, denominada de função de redistributividade e supletiva em matéria de educação, de forma a garantir equalização de oportunidades educacionais e padrão mínimo de qualidade de ensino. Dai dizer que o desvio desses recursos é da competência da Justiça Federal, vez que cuida-se de crime em detrimento de um serviço da União. ${ }^{6}$

Esclarece, André Medeiros do Paço (2000, p.60):

${ }^{5}$ STF - RTJ 135/672; RECR 162.966/RS, Tribunal do Pleno, Rel. Min. Neri da Silveira, j. 27.05.1993, DJ 08.04.1994.

${ }^{6}$ STF, 1aㅡ Turma, Rel. M in. Sepúlveda Pertence,j.27.06.1997, DJ 12.09.1997, p. 43.714. 
[...] As prefeituras celebram convênios com órgãos estaduais e federais, recebendo recursos para a realização de variados empreendimentos: reforma de escolas, construção de postos de saúde, quadras esportivas etc. 0 dinheiro é deositado em conta bancaria especialmente aberta para recebê-la e assim facilitar seu controle e fiscalização. Todavia, quando o Prefeito apropriar-se dessas verbas de origem federal em proveito próprio ou de terceiro, qual a Justiça competente para 0 processo penal originário? As Súmulas do Superior Tribunal de Justiça definem os termos da questão ao afirmar que, se houver necessidade de prestação de contas do órgão federal convevente ao Tribunal de Contas da União, cabe à Justiça Federal o processo e julgamento.

Competência pela prerrogativa de função e a competência do tribunal do júri

É sabido que o Tribunal do Júri é um órgão jurisdicional de primeiro grau (art. 5으, inciso XXXVIII, alínea d, CF), em contrapartida a competência estabelecida pela prerrogativa de função, fica submetida ao julgamento por órgãos hierarquicamente superiores. Simples seria 0 entendimento de vigorar o foro por prerrogativa de função, cujo interesse norteador é impor a intervenção originária de órgãos jurisdicionais superiores quando partes no processo são pessoas que exercem determinadas funções públicas, em detrenimento da competência privativa para o julgamento de causas que contenham pretensão punitiva fundada em fatos configuradores de crimes dolosos contra a vida, ambas com igual sede constitucional (KARAM, 2005, p. 300).

Porém, é de bom alvitre lembrar que a instituição do júri, está inserida no título onde estão dispostos os direitos e garantias fundamentais e partindo do princípio de que a competência do júri detém qualificação hierarquicamente superior em razão da regra que expressa 0 foro por prerrogativa de função, pois esta não esta dentro dos direitos fundamentais, assim cederia à aplicação da competência do Júri.

Entretanto, Maria Lúcia Karam (2005, p. 122) insiste no entendimento de que a simples inserção da competência do júri dentre direitos e garantias fundamentais não possibilita a prevalência deste sobre a prerrogativa de função, já que todas as regras constitucionais sobre competência, em última análise, acabam por se situar, ainda que indiretamente naquele título, "na medida em que constituem uma espécie de complemento da regra enunciada no inciso LIII do artigo $5^{\circ}$, funcionando como instrumentos de materialização de seu conteúdo"., ou seja, as regras de cunho constitucional sobre competência buscam traduzir e efetivar o principio do juiz natural. 
Ainda que diante do reconhecimento da competência do júri como direito do Prefeito como cidadão e não como exercente de cargo público, Maria Lucia Karam (2005, p. 124-125), baseando - se na letra da lei, diz que em nenhuma regra constitucional de competência originária de órgãos superiores para o conhecimento de causas que contenham pretensão fundada na prática de infração penal por ocupantes de cargos públicos, existe ressalva quanto a infrações penais incluídas na competência do júri.

Ainda reitera que embora criticável a opção política pela defesa do interesse do Estado em garantir a preservação da dignidade e da relevância de cargos públicos, através da intervenção no processo tão somente de órgãos jurisdicionais de graduação superior, ao invés do direito individual do cidadão que ocupa tais cargos públicos, este direito será sacrificado em prol de um interesse da coletividade.

A discussão está em torno de dois interesses estatais de idêntico patamar, ambos vinculados à concretização do juiz natural.

Sendo um confronto de regras constitucionais de mesma valia e mesmo patamar hierárquico, além do próprio direito à liberdade do indivíduo, a autora Maria Lucia Karam (2005, p. 126), com o intuito de amenizar os interesses em confronto, expõe a seguinte idéia:

[...] estabelecendo-se a competência do júri tão-somente para a fase do julgamento submetida a admissibilidade da acusação ao exame dos órgãos jurisdicionais superiores e indicado para presidir a sessão de julgamento órgão integrante do Tribunal a quem competisse aquele exame da admissibilidade da acusação, de forma a evitar que ocupantes de cargos públicos de maior dignidade e relevância se vissem processados perante juizes togados de primeiro grau.

Ainda sobre o tema, cabe observar que o Supremo Tribunal Federal, na hipótese de competência originária dos Tribunais de Justiça, estabelecida pelas Constituições Estaduais, nos termos da autorização presente no artigo 125 , em seu $\S 1$ o da Constituição Federal em contraposição a regra contida no artigo 50 , inciso XXXVIII, alínea d, que estabelece a competência do júri, consagrou o entendimento de que a esta se sobrepõe àquela, ou seja, afasta as normas de competências presente nas Constituições Estaduais. Tal entendimento resultou na Súmula 721 daquela corte, assim enunciado: "A competência constitucional do Tribunal do Júri prevalece sobre o foro por prerrogativa de função estabelecida exclusivamente pela Constituição Estadual". 
Caso venha estabelecido na própria Constituição Federal o foro por prerrogativa de função, será esta competência que devera prevalecer. Assim, se, por exemplo, um deputado federal (art.102, I. b) ou um promotor de justiça (art. 96, III) cometerem crime doloso contra a vida, o julgamento ficará, respectivamente, a cargo do SupremoTribunal Federal ou do Tribunal de Justiça, porque a competência originaria destes tribunais, em ambos casos, esta prevista na nossa Carta M aior. Embora prevista também constitucionalmente a competência do Júri, esta não poderia sobrepor-se a competência originária estabelecida pelo mesmo texto.

Vale elucidarmos tal situação com o acórdão do ST): “Competência do Tribunal de
Justiça firmada na conformidade do disposto no art. 96 , III, da Constituição Federal.
Conquanto constitucionalmente definida a competência do Tribunal do Júri, para o
processo e julgamento dos crimes dolosos contra a vida, não pode sobrepor-se do
Tribunal de Justiça, por prerrogativa de função, igualmente cometida pela
Constituição"

Sobre 0 assunto entende Ney M oura Teles (2006, p. 92), ser justo a prevalência do foro por prerrogativa de função, submetendo o Prefeito ao julgamento do Tribunal de Justiça e não ao Tribunal do Júri, no caso por exemplo de homicídio doloso, pois estaríamos diante de um júri popular, composto por cidadãos leigos da sociedade, dotados de competência para julgar e que "é de se antever que dificilmente um prefeito seria condenado, dada a força do prestígio junto aos seus pares, ou do temor que infunde, igualmente".

Resumindo as idéias discutidas temos que: se a competência especial por prerrogativa de função estiver estabelecida na Constituição Federal, prevalecerá sobre a competência constitucional do Júri, em razão da matéria; se o foro especial estiver estabelecido em lei ordinária ou lei de organização judiciária, prevalecerá a competência constitucional do Júri; se o foro especial tiver previsão em Constituição estadual, prevalecerá a competência do Júri. (CAPEZ, 2004, p.197)

Tal interpretação prestigia a relevância dada na Constituição Federal à competência privativa do júri para o julgamento de causas que contenham pretensão punitiva em fatos configuradores de crimes dolosos contra a vida, ao ressaltar que a regra do artigo 5ㅇ, inciso XXXVIII, alínea $d$, cede "apenas diante de regras que, estabelecendo a competência por

\footnotetext{
${ }^{7}$ RSTJ, 21/96.
} 
prerrogativa de função, encontram sua sede também na Constituição Federal" (KARAM, 2005, p. 127).

De maneira indireta o Pretório Excelso, ratificou que a prerrogativa de foro, fixada na Constituição Federal, excepciona a competência genérica do júri, para delitos dolosos contra a vida. Por outro lado, se o foro privilegiado for obtido por Disposição de Constituição Estadual, devem as autoridades, serem processadas no Tribunal do Júri, pois esta não pode prevalecer sobre norma constitucional federal,mesmo diante do seu caráter genérico. ${ }^{8}$

\section{0 cabimento da perpetuaçấo da competência por prerrogativa de função para ex - ocupantes de cargo público}

0 foro por prerrogativa de função persistia mesmo após o encerramento do mandato, desde que tivesse sido cometida a infração penal durante o exercício funcional, diante do término da função, a Súmula 394 do STF, editada em 1964, sempre garantiu a continuidade do foro privilegiado, sob o argumento de que já havia ele sido fixado no momento da prática delituosa.

Ocorre que no dia 25 de agosto de 1999, o STF cancelou a referida Súmula, sustentado que as prerrogativas de foro especial devem ser interpretadas de forma restritiva, na medida em que excepcionam o princípio de igualdade entre os cidadãos.

Situação esta que vigorou por pequeno espaço de tempo, pois em 26 de dezembro de 2002, mesma data de sua publicação, entrou em vigor a Lei n. 10.628, de 24 de dezembro do mesmo ano, no Governo de Fernando Henrique Cardoso, o qual conferiu nova redação ao artigo 84 do Código de Processo Penal e lhe acrescentou dois parágrafos.

E mais uma vez a população brasileira passou desapercebida ao interesse político de impedir o seu conhecimento sobre o Projeto $n .0$ 6.295/02, inteiramente lesivo ao interesse público, estendendo o benefício do foro privilegiado aos ex-ocupantes de cargos públicos, pois foi em meio aos jogos finais da Copa do Mundo de Futebol de 2002 que se fez tramitar no Congresso Nacional, quando as atenções da Nação e da imprensa estavam voltadas para as questões futebolísticas (M ARCÃO, 2005).

\footnotetext{
${ }^{8}$ Nesse sentido as decisões jurisprudenciais: STJ, HC 1.999, 5 a Turma, DJU 20.09.94, p. 19184; STF, RECrim 01.629.665/210, Plenário, RT 710/363.
} 
A Lei 10.628/02 contraria a Constituição Federal; todo e qualquer senso de Justiça; princípios constitucionais basilares; 0 interesse social, e não corresponde, em absoluto, com as idéias e ideais da sociedade brasileira contemporânea, representando, sem sombra de dúvida, ranço primitivo e ditatorial, e os homens primitivos, conforme LUCIEN LÉVY-BRUHL, "vivem, pensam, sentem, se movem e agem num mundo que em numerosos pontos não coincide com o nosso" (M ARCÃO, 1947, p. 47).

Entende-se que encerrado o exercício funcional, desde de que crime não tenha nenhuma relação com a função, cessa o foro especial, devendo o processo, se ainda não proferida a decisão final, ser remetido à jurisdição de primeiro grau. Por exemplo; homicídio doloso ou culposo, lesões corporais dolosas cometidas no âmbito doméstico, furto em padaria, enfim situações que não forem consideradas ato administrativo do agente (TOURINHO, 2004, p. 199).

Nesse sentido faz jus mencionar a Súmula 451 "A competência especial por prerrogativa de função, não se estende ao crime cometido após a cessação definitiva do exercício funcional".

Vale lembrar que o crime praticado pelo chefe do Poder Executivo municipal, durante o seu mandado, em violação ao art. 1 do Decreto-Lei n. 201/67, e já consumado, obviamente não desaparece com o término do mandato, devendo ser processado. E o teor da Súmula 164 ST): "O prefeito municipal, após a extinção do mandato, continua sujeito por crime previsto no art. 1 do Decreto-Lei n. 201/67, de 27 de fevereiro de 1967".

Bem como a Súmula 703 do STF: "A extinção do mandato do prefeito não impede a instauração de processo pela prática dos crimes previstos no art. 1 do Decreto-Lei n. 201/67".

Diante do entendimento de Alexandre de Moraes a respeito da competência originária do Supremo Tribunal Federal, aplicaremos subsidiariamente à competência originária do Tribunal de Justiça, no que se refere aos Prefeitos Municipais, assim sendo "encerrado o exercício do mandato/cargo e, consequentemente, cessada a prerrogativa de foro, não mais subsistirá a competência do Supremo Tribunal Federal", no caso em análise não prevalecerá a competência do Tribunal de Jusitiça, "para o processo e julgamento, uma vez que o próprio Tribunal, por unanimidade, cancelou a Súmula n. 394" (RAM OS FILHO, 2007). 
Como se observa, a Constituição Federal de 1.988 não incluiu o julgamento dos exagentes políticos na esfera de atribuições jurisdicionais originárias dos tribunais, ainda que propostas em face dos agentes políticos que gozavam de foro especial por prerrogativa de função quando do exercício de suas funções. A competência constitucional e originária do Tribunal de Justiça, no que toca ao julgamento de autoridades estaduais e municipais, restringe-se aos crimes comuns e aos de responsabilidade, nos termos do artigo 125, §1으, da Constituição Federal. ${ }^{9}$

A Constituição do Estado do Paraná, em seu artigo 102, inciso VII, letra "a", prevê a competência privativa do Tribunal de Justiça para processar e julgar, originariamente, dentre outras autoridades, os prefeitos municipais, estando em conformidade com 0 artigo 29, X, da Constituição Federal.

Assim, nem o texto constitucional federal e nem o texto estadual estabelecem competência para ex-agente público, no caso, para ex-prefeito municipal.

\section{Conclusão}

Sabemos que o Estado Democrático de Direito, possui princípios e interesses tidos como relevantes, dentre eles podemos citar o princípio da isonomia que relacionado com 0 foro por prerrogativa de função podemos entender que este torna-se exceção daquele, mesmo afirmando que tal tratamento especializado diz respeito à função pública desempenhada e não à pessoa que a desempenha, situação esta que não merece muita credibilidade, já que podemos notar que atuação do Chefe do Poder Executivo Municipal não cumpre com o seu dever na busca incessante à realização do bem comum, utilizando tal instituto apenas para servir interesses pessoais.

Noutro falar, há entendimento de que a competência pela prerrogativa de função não transgride o princípio da isonomia, apenas garante um interesse de ordem pública, ou seja, a necessidade de resguardar a dignidade e importância para o Estado de determinados órgãos públicos, não sendo então um privilégio de uns em detrimento de outros.

\footnotetext{
${ }^{9}$ RAMOS FILHO, Cristóvam Joaquim. Da Legislação Processual e Penal Aplicável aos Prefeitos - Histórico e Entraves Enfrentados. Disponível em: http:// www.sindimp.com.br/lerartigo.asp?cod=104. Acesso em: 08 de maio de 2007.
} 
Diante da omissão do art. 29, inc X, da Constituição Federal, fez-se necessário distinguir crime comum e crime de responsabilidade, e na tentativa de suprimir tal omissão a jurisprudência tem entendido que, 0 art. 29 inc $X$, da CF/88, abrange ambos, desde que sejam submetidos à Justiça Estadual.

Entende-se que crimes de responsabilidade é um crime funcional, decorrente do exercício da atividade laborativa nos cargos públicos. Enquanto que crime comum compreende todas as modalidades que não se enquadrem no rol dos crimes de responsabilidade. Não podendo confundir com as infrações político - administrativas que não serão submetidas ao Poder Judiciário, e sim à apreciação da Câmara dos Vereadores.

Quanto ao crime eleitoral cometido por Prefeito Municipal temos um concurso aparente, entre a competência do Tribunal de Justiça para o processo e julgamento e 0 Tribunal Regional Eleitoral, neste caso não há maiores questionamentos de que a preponderância do interesse criador da prerrogativa de função não afastará a intervenção dos órgãos jurisdicionais instituídos especialmente para examinar matéria eleitoral.

Admite-se entendimento oposto ao acima citado, daqueles que afirmam que ao afastarmos a competência do Tribunal de Justiça para julgar matéria eleitoral estaríamos transgredindo o princípio do Juiz Natural, princípio este previsto no art. 50, inc. LIII, da Constituição Federal de 1988 , encerrando uma garantia constitucional, de uma lado limitando, os poderes do Estado, impossibilitando-o de estabelecer juízos ad doc ou de criar Tribunais de exceção e de outro lado assegura ao acusado o direito ao processo perante autoridade competente.

$\mathrm{Na}$ hipótese de ser deduzida pretensão punitiva fundada em fatos configuradores que atinja bens, serviços ou interesse da União, de suas autarquias ou de empresas públicas federais desvincula-se o foro por prerrogativa de função e possibilita a influência da União em detrimento dos Estados Membros, de maneira que a competência originária passará ser do Tribunal Regional Federal e não mais do Tribunal de Justiça.

0 Tribunal Regional Federal também é órgão com competência originária que afasta a prerrogativa de função para processar e julgar crimes políticos por se tratar de condutas delitivas que afrontam de modo imediato o Estado em sua unidade orgânica de instituições políticas e sociais. 
Na tentativa de demonstrar a competência, diante do desvio de verbas praticado por Prefeito municipal, nos remetemos às Súmulas 208 e 209, para dizer que se a verba desviada era sujeita a prestação de contas perante órgão federal, fica evidente o interesse da União, causa esta submetida ao julgamento pelo Tribunal Regional Federal. Competente será o Tribunal de Justiça se tal verba já havia sido incorporada ao patrimônio do M unicípio, situação em que não cabe a intervenção da União.

Não resta dúvida que o Tribunal de Justiça é competente originariamente para processar e julgar crimes sejam eles comuns ou de responsabilidade cometidos por Prefeitos Municipais, entretanto cizânia há, quando do cometimento de infração penal cuja competência é do Tribunal do Júri, nota-se, existe o interesse da dignidade e importância do cargo público e o interesse subjetivo do Prefeito como cidadão, ambos previsto na Constituição Federal.

Temos que se a competência por prerrogativa de função estiver estabelecida apenas em Constituição Estadual prevalece o Tribunal do Júri, vez que aquela não se sobrepõe a esta, entretanto, se o foro especial também estiver previsto na Constituição Federal, a regra especial vigorará sobre a geral, ou seja, o Tribunal de Justiça é o órgão competente para processar e julgar prefeito municipal quando do cometimento de crime doloso contra a vida.

Observou - se que a doutrina majoritária opta pela preponderância do foro por prerrogativa de função, sacrificando o interesse individual em nome da coletividade, admitindo entendimento contrário. Diante de tal situação que pode causar mal - estar na população, por se tratar de um bem maior que é a liberdade do individuo, propõe-se que seja submetido ao Tribunal do Júri o julgamento, enquanto que os órgãos superiores seriam responsáveis pela fase de admissibilidade, na tentativa de resguardar a importância da função pública desempenhada e o direito de ser julgado pelo Júri Popular, instituto que guarda certas particularidades.

Não podemos olvidar que o fato de permanecer a prerrogativa de função em face de crimes dolos contra a vida, prevê a impunidade, pois partindo do princípio de que tal prerrogativa não é um privilégio de cunho pessoal e sim um instrumento para resguardar a relevância do cargo público, submeter o Prefeito municipal ao julgamento pela primeira 
instancia diante do seu prestígio perante a sociedade ou por temor desta poderia restar prejudicada a sanção.

Quanto ao cabimento da competência por prerrogativa de função ainda que sejam as autoridades, ex - ocupantes de cargo público temos que, em 1999 a Suprema Corte cancelou a Súmula 394 que garantia aos ex-agentes o processo e julgamento pelos órgãos superiores, entretanto em 2002 foi editada a Lei 10.628, que acrescentou $0 § 10$ do art. 84 do Código de Processo Penal, que prevê a perpetuação do foro por prerrogativa de função a ex - ocupantes de cargos público, o que desembocou na instauração da ADIn no. 2797/600 DF, que por sua vez declarou a inconstitucionalidade de tal parágrafo, já que o legislador ordinário não tem o condão de editar norma de natureza constitucional, dando interpretação diferente do que já está estabelecido em nossa Lei M aior.

Inadmissível essa tentativa de ampliar o rol dos que estão sob a égide do foro por prerrogativa de função em uma Constituição que pretende tratar igualmente os cidadãos comuns, trata-se de ex-exercente de função pública, não havendo qualquer interesse público legitimador de modificação da regra da igualdade constitucional.

Como dizer em competência por prerrogativa de função se pretende garanti-la a pessoa que não mais exerce a função, não havendo qualquer interesse público na concessão de tal privilégio.

Note-se, por derradeiro, que a competência dos Tribunais vem delimitada no texto constitucional e a norma infraconstitucional não pode ampliar o rol de competências dos Tribunais conforme estabelecido, inclusive em razão de princípios como os da hierarquia e verticalidade das normas.

Nesse sentido não podemos olvidar do entendimento emitido pela Associação dos Juízes Federais que afirma ser o foro por prerrogativa de função uma contribuição para a sensação de impunidade no Brasil, deixando evidente tal situação as notícias que cotidianamente são veiculadas pelos meios de comunicação sob diferentes denominações, como Anaconda, Hurricane, Thêmis, Navalha, nomes atribuídos às operações da Polícia Federal que demonstram escândalos e torpeza de muitos políticos.

Trata-se, a bem da verdade de um desrespeito ao princípio republicano de igualdade, assim como um fomento à criminalidade política e à corrupção. 


\section{Referências}

CAPEZ, Fernando. Curso de Processo Penal. 11. ed. São Paulo: Saraiva, 2004.

CARNEIIRO, Athos Gusmão. Jurisdição e Competência. 13. ed. São Paulo: Saraiva,2004.

CINTRA, Antônio Carlos de Araújo Cintra; GRINOVER, Ada Pellegrini; DINAM ARCO, Cândido Rangel. Teoria Geral do Processo. 19. ed. São Paulo: Malheiros, 2003.

FLÁVIO, Renato Marcão. Foro especial: o M inistério Público e o Tribunal de Justiça de São Paulo firmam posições em ações de improbidade. Disponível em: বhttp:/www.damasio.com.br/novo/html/frame_artigos.htm>. Acesso em: 29 jun. 2005.

FLÁVIO, Renato Marcão. Foro por Prerrogativa de Função. 0 Novo Artigo 84 do Código de Processo Penal. Disponível em: বtttp://www.mundojuridico.adv.br/documentos $>$. Acesso em: 18 jun. 2005.

FRANCO, Alberto Silva. Código de Processo Penal e sua Interpretação Jurisprudencial. 2. ed. São Paulo: Revista dos Tribunais,2001. v. 2.

KARAM, Maria Lúcia. Competência no Processo Penal. 4. ed. São Paulo: Revista dos Tribunais, 2005.

M ARQUES, José Frederico. Elementos de Direito Processual Penal. São Paulo - Rio, 1961. v. 1.

M IRABETE, Júlio Fabrini. Código de Processo Penal Interpretado. 11. ed. São Paulo: Atlas,2003.

M IRABETE, Júlio Fabrini. Processo Penal. 18. ed. São Paulo: Atlas, 2006.

NORONHA. E. Magalhães. Curso de Direito Processual Penal. 28. ed. São Paulo: Saraiva, 2002.

NUCCl, Guilherme de Souza. M anual de Processo Penal e Execução Penal. 3. ed. São Paulo: Revista do Tribunais, 2007.

PAÇO, André M edeiros do. Foro por Prerrogativa de Função: Prefeitos M unicipais. Belo Horizonte: Del Rey, 2000.

RAM OS FILHO, Cristóvam Joaquim. Da Legislação Processual e Penal Aplicável aos Prefeitos Histórico e Entraves Enfrentados. Disponível em: বhttp:// www.sindimp.com.br/lerartigo.asp?cod=104>. Acesso em: 08 maio 2007. TELES, Ney M oura. Direito Penal: Parte Geral: art.1o a 120. 2. ed. São Paulo: Atlas, 2006. v. 1.

TORNAGHI, Hélio. Instituições de Processo Penal. 1. ed. Rio de Janeiro: Forense.1959. v. 2. 
TOURINHO, Fernando da Costa Filho. Código de Processo Penal Comentado. 8. ed. São Paulo: Saraiva, 2004. v. 1. 